\title{
Pelatihan Mindfulness untuk Menurunkan Kecemasan Ibu dengan Kehamilan Pertama Trimester III
}

\author{
NURUL HAPSARI*, SUCI MURTI KARINI, \& ARIF TRI SETYANTO \\ Program Studi Psikologi, Fakultas Kedokteran Universitas Sebelas Maret
}

\begin{abstract}
ABSTRAK
Tujuan intervensi adalah untuk menguji pengaruh pelatihan mindfulness untuk menurunkan kecemasan ibu dengan kehamilan pertama (primigravida) trimester III. Partisipan intervensi berjumlah tiga orang ibu hamil. Setiap partisipan mengikuti pelatihan mindfulness sebanyak delapan sesi, yang di dalamnya terdapat praktik kesadaran bernapas, scan tubuh, kesadaran makan, dan yoga kehamilan. Penulis menggunakan desain single-case experimental tipe A-B dengan kondisi baseline tujuh hari dan kondisi intervensi 14 hari. Analisis data menggunakan teknik statistik deskriptif melalui analisis visual dengan grafik kuantitatif dan kualitatif. Partisipan diberikan buku harian ibu hamil untuk mengukur perubahan kecemasan tiap harinya, wawancara, dan observasi. Hasil intervensi menunjukkan bahwa pada partisipan 1 dan partisipan 3 terjadi penurunan mean kecemasan kehamilan, sedangkan pada partisipan 2 mengalami peningkatan. Pelatihan mindfulness tidak berpengaruh pada seluruh partisipan. Hal tersebut dikarenakan partisipan 2 lebih dipengaruhi oleh adanya faktor pengalaman kuat yang didapatkan dari lingkungan kerja dan belum dapat menginternalisasi penuh komponen mindfulness yaitu kesadaran terbuka, fokus, dan tidak menghakimi.
\end{abstract}

Kata kunci: kecemasan, mindfulness, primigravida, single-case, trimester III

\begin{abstract}
The intervention aim was to examine the effect of mindfulness training to reduce anxiety at third trimester of first pregnancy (primigravid) women. The participants were three pregnant women. Each participant followed the eight-sessions training, which include mindfulness breathing, body-scan, mindfulness eating, and yoga pregnancy. We used single-case experimental design type A-B by recording baseline condition for seven days and intervention condition for 14 days. Data analysis using descriptive statistical technique through graphical visual analysis by quantitative and qualitative analysis. We asked participants to fill a daily journal to measure the anxiety level, conducting interview, and observation. The results showed that participant 1 and participant 3 , there was a mean decrease pregnancy anxiety, while participant 2's anxiety level was increased. The intervention of mindfulness training has no effect on all participants, because the participant 2 was more influenced by a strong experience factor gained from her work environment and she was not able to internalize the full component of mindfulness, including open awareness, focused, and non-judgemental.
\end{abstract}

Keywords: anxiety, mindfulness, primigravid, single-case, third trimester 
INSAN Jurnal Psikologi dan Kesehatan Mental, 2021, Vol. 6(1), 10-21, doi: 10.20473/jpkm.v6i12021.10-21 Dikirimkan: 19 September 2018 Diterima: 1 November 2020 Diterbitkan: 1 Januari 2021

Editor: Rizqy Amelia Zein

*Alamat korespondensi: Jalan Elang B5/34 Lingkungan Puri Gading, Jimbaran, Kuta Selatan, Badung, Bali 80361. Surel: nurulhapsari96@gmail.com

Naskah ini merupakan naskah dengan akses terbuka dibawah ketentuan the Creative Common Attribution License (http://creativecommons.org/licenses/by/4.0), sehingga penggunaan, distribusi, reproduksi dalam media apapun atas artikel ini tidak dibatasi, selama sumber aslinya disitir dengan baik.

\section{PEN D A H U L U A N}

Kecemasan merupakan bentuk dari perasan yang kurang menyenangkan seperti gelisah dan khawatir terhadap suatu hal (Hurlock, 1990). Roomer dan Orsillo mengungkapkan bahwa kecemasan dicirikan dengan adanya hubungan pemikiran yang sempit, reaktif, dan sikap menghakimi terhadap pengalaman internal (dalam Brown, Creswell, \& Ryan, 2015). Seseorang akan terjebak dalam keinginan yang kaku untuk melakukan penghindaran terhadap suatu pengalaman dan perilaku yang dirasakannya sebagai suatu ancaman.

Kecemasan merupakan salah satu faktor yang banyak mengganggu kesehatan psikologis ibu hamil. Berdasarkan penelitian yang dilakukan oleh Biaggi, Conroy, Pawlby, dan Pariante (2016) prevalensi kejadian kecemasan kehamilan pada negara maju sekitar 7-20 persen dan di negara berkembang lebih dari 20 persen. Fariana (2007) menyatakan bahwa kecemasan kehamilan merupakan kondisi munculnya perasaan khawatir dan gelisah terhadap objek yang belum jelas terkait dengan kondisi kesehatan ibu dan bayi yang dikandung. Perasaan khawatir dan gelisah muncul disebabkan oleh adanya perasaan tidak mampu menjalani kehamilan yang dipengaruhi dari dalam dan luar individu. Kecemasan kehamilan memiliki dua aspek yaitu gejala fisik dan gejala psikologis (Fariana, 2007) . Gejala fisik meliputi munculnya peningkatan denyut nadi, sistem pencernaan terganggu, lemas, pusing, kesulitan tidur, badan berkeringat walaupun suhu sedang dingin, dan badan gemetar. Gejala psikologis meliputi sulit konsentrasi, takut, gelisah, perasaan tak berdaya, tegang atau mudah marah, mimpi buruk, dan khawatir (Fariana, 2007).

Kecemasan kehamilan yang dibiarkan dapat membawa dampak negatif bagi proses kehamilan dan masa setelah persalinan. Schetter dan Tanner (2012) menjelaskan, kecemasan pada kehamilan dapat meningkatkan risiko kelahiran prematur, rendahnya berat badan anak, dan kemungkinan gangguan syaraf pada anak. Kecemasan memiliki hubungan dengan meningkatnya hipertensi individu sehingga berbahaya bagi kehamilan (Pan, dkk., 2015). Risiko bunuh diri pun meningkat seiring tingginya kecemasan kehamilan yang terjadi pada trimester III dan satu bulan setelah persalinan (Schermerhorn, 2015). Pada masa setelah persalinan, kecemasan kehamilan dapat mengganggu produksi kelenjar susu ibu yang diakibatkan oleh turunnya konsentrasi prolaktin (Bora, Rahman, \& Hasina, 2013). Kecemasan kehamilan juga menjadi prediksi tingginya stres pada tiga bulan pertama setelah kelahiran (Huzink, dkk., 2017).

Spielberg dan Saranson menyatakan beberapa faktor yang menjadi pemicu timbulnya kecemasan kehamilan, diantaranya adalah pengalaman, kehamilan yang tidak dikehendaki, kehamilan tidak sah, dan keturunan (dalam Hidayati, 2014). Faktor-faktor tersebut secara garis besar berhubungan dengan faktor kognitif yang ditandai dengan pemikiran sempit, reaktif, dan sikap menghakimi pengalaman yang sedang dilalui. 
Salah satu kondisi ibu hamil yang memiliki risiko kecemasan kehamilan yang tinggi adalah ibu dengan kehamilan pertama trimester III. Ibu dengan kondisi ini memiliki risiko kecemasan kehamilan lebih tinggi dibandingkan dengan ibu hamil lainnya (Goodman, dkk., 2013). Hal tersebut sesuai dengan studi pendahuluan berupa wawancara yang telah dilakukan pada Desember 2017 di Puskesmas Sibela, Mojosongo, Surakarta. Hasil studi pendahuluan menunjukkan data bahwa ibu dengan kehamilan pertama trimester III memiliki rasa cemas yang mengganggu. Beberapa penelitian menunjukkan bahwa ibu dengan kehamilan pertama trimester III memiliki rata-rata tingkat kecemasan kehamilan sedang hingga berat (Handayani, 2015) (Wulandary, 2014) . Bila dibandingkan dengan ibu yang memiliki pengalaman kehamilan, ibu dengan kehamilan pertama memiliki kesiapan mental yang lebih rendah (Litsmanasari \& Warsiti, 2013).

Menurut Roomer dan Orsillo, salah satu bentuk intervensi psikologis yang dapat mereduksi kecemasan adalah pelatihan mindfulness (dalam Brown, Creswell, \& Ryan, 2015). Pelatihan mindfulness merupakan pelatihan yang mengadopsi suatu gagasan dari Budha. Zinn mengungkapkan bahwa mindfulness memiliki tiga komponen utama yaitu memberi perhatian penuh dengan cara tertentu, momen saat ini, dan tidak menghakimi (Zarbock, Lynch, Ammann, \& Ringer, 2015). Pelatihan ini memiliki dua jenis utama yaitu Mindfulness-Based Stress Reduction (MBSR) dan Mindfulness-Based Cognitive Therapy (MBCT).

Menurut McManus, dkk. (2012) dalam penelitiannya menunjukkan bahwa pelatihan mindfulness berguna untuk diberikan pada pasien yang memiliki gangguan kecemasan kesehatan (hypochondriasis). Penelitian terdahulu yang dilakukan oleh Maharani (2013) memberikan pelatihan mindfulness pada ibu hamil. Hasil penelitan menunjukkan bahwa pelatihan mindfulness secara signifikan mampu menurunkan tingkat distress pada aspek fisik, perilaku, kognitif, dan emosi.

Berdasarkan uraian diatas, penulis mencoba menggali mengenai pengaruh pelatihan mindfulness terhadap kecemasan kehamilan, khususnya bagi ibu dengan kehamilan pertama trimester III. Tujuan utama penelitian ini adalah untuk merumuskan apakah terdapat pengaruh pelatihan mindfulness terhadap kecemasan pada ibu dengan kehamilan pertama trimester III. Penelitian ini diharapkan mampu memberikan manfaat praktis dan menambah kajian ilmu mengenai pentingnya memberi perhatian pada aspek psikologis ibu hamil di samping aspek medis dalam persiapan menuju persalinan.

\section{MET ODE}

\section{Partisipan Intervensi}

Partisipan dalam intervensi ini berjumlah tiga orang dengan karakteristik ibu dengan kehamilan pertama yang sedang berada pada periode kehamilan trimester III (menginjak bulan ketujuh hingga kesembilan kehamilan), riwayat pendidikan minimal sekolah dasar dengan tujuan penyetaraan proses transfer materi, belum pernah mengikuti intervensi berbasis mindfulness sebelumnya, serta tidak memiliki riwayat gangguan biologis dan psikologis yang berat. Sebelum intervensi diberikan, penulis menjelaskan keseluruhan prosedur, hak, dan kewajiban yang harus ditaati oleh partisipan. Ketiga partisipan bersedia menjadi partisipan, ditandai dengan penandatanganan informed consent. Seluruh partisipan menandatangani informed consent sebagai bentuk persetujuan dengan seluruh prosedur intervensi yang diberikan. 


\section{Prosedur Intervensi}

Seluruh prosedur intervensi yang disampaikan sesuai dengan modul pelatihan mindfulness yang disusun oleh penulis. Pelatihan mindfulness disampaikan dengan bantuan seorang fasilitator yang berprofesi sebagai Psikolog Klinis. Pelatihan mindfulness terdiri dari delapan sesi yang dilakukan dalam tiga kali pertemuan. Sesi 1, 2, dan 3 dilaksanakan pada pertemuan pertama. Sesi 4 dan 5 dilaksanakan pada pertemuan kedua. Terakhir, sesi 6, 7, dan 8 dilaksanakan pada pertemuan ketiga. Selama jeda pertemuan pelatihan, partisipan juga diminta untuk mengaplikasikan praktik mindfulness secara mandiri. Partisipan tetap mengisi buku harian ibu hamil setiap hari, sejak pelatihan belum diberikan hingga selesai. Hal tersebut bertujuan untuk mengukur tingkat kecemasan yang dimiliki partisipan dan juga sebagai media untuk memantau praktik mandiri yang dilakukan. Berikut merupakan prosedur intervensi dan penjelasan tiap sesi.

1. Sesi 1: Pengenalan. Pada sesi ini fasilitator membangun rapport dengan tujuan agar selama intervensi dilakukan, partisipan merasa nyaman dan termotivasi.

2. Sesi 2: Mindfulness Kehamilan. Sesi ini merupakan sesi psikoedukasi mengenai mindfulness dan kehamilan. Penjelasan mengenai mindlessness dan manfaat mindfulness juga diberikan. Partisipan diminta untuk menceritakan pikiran, perasaan, dan perilaku yang dilakukan selama proses kehamilan.

3. Sesi 3: Mindfulness Berpikir. Sesi ini merupakan tahap partisipan mengerti mengenai cara berpikir mindfulness. Fasilitator menjelaskan mengenai decentered disertai dengan contoh.

4. Sesi 4: Kesadaran Bernapas. Pada sesi ini, fasilitator menjelaskan mengenai latihan formal mindfulness pada partisipan. Fasilitator juga menekankan pada sikap-sikap yang harus dimiliki ketika akan berlatih kesadaran bernapas. Simulasi dilakukan selama dua kali yaitu kesadaran bernapas sederhana (5 menit) dan kesadaran bernapas leih lanjut (20 menit).

5. Sesi 5: Kesadaran Makan. Fasilitator menjelaskan bahwa mindfulness tidak hanya dapat dilatih dalam hal formal, melainkan kegiatan sehari-hari juga dapat menjadi sarananya. Penyampian beberapa contoh dan proses mindfulness di kehidupan sehari-hari. Setelah itu, dilanjutkan dengan simulasi kesadaran makan. Fasilitator memandu dengan instruksi saat partisipan makan.

6. Sesi 6: Scan Tubuh. Pada awal sesi disampaikan psikoedukasi mengenai scan tubuh terkait fungsinya, manfaat nya dengan kehamilan, dan sensasi-sensasi yang mungkin dirasakan selama berlatih. Simulasi dilakukan dibawah instruksi dari fasilitator.

7. Sesi 7: Yoga Kehamilan. Penyampaian materi mengenai yoga kehamilan, terkait mindfulness yang membedakan dengan yoga kehamilan pada umumnya. Praktik yoga kehamilan yang diinstruksikan dan dicontohkan oleh fasilitator kemudian diikuti partisipan.

8. Sesi 8: Penutup. Tujuan sesi ini adalah meringkas ketiga pertemuan pelatihan mindfulness yang telah dilakukan. Fasilitator dan partisipan secara bersama-sama mengambil kesimpulan dan pembelajaran dari hasil pelatihan mindfulness. Fasilitator memberi motivasi partisipan untuk terus melatih kesadaran, fokus, dan sikap tidak menghakimi di setiap kegiatan yang dijalani oleh partisipan.

Desain intervensi yang digunakan adalah single-case experimental design. Desain ini menggunakan pengukuran keadaan awal (baseline) yang dilakukan sebelum intervensi diberikan pada partisipan (Sunanto, Takeuchi, \& Nakata, 2005) . Intervensi ini menggunakan kategori reversal tipe A-B yaitu dengan melakukan pengukuran perilaku sekurang-kurangnya dua kondisi yaitu kondisi baseline (A) dan kondisi intervensi (B). Rentang waktu kondisi baseline selama tujuh hari berturut-turut sebelum pelatihan mindfulness diberikan, sedangkan rentang waktu intervensi selama 14 hari yaitu sejak pertemuan pertama pelatihan hingga latihan mandiri pelatihan mindfulness selesai dilakukan. 
Pengukuran dilakukan pada variabel kecemasan yang dimiliki tiap partisipan. Perbandingan bukan dilakukan antar partisipan, melainkan pada partisipan yang sama dalam kondisi yang berbeda.

\section{Pengukuran Efektivitas Intervensi}

Pengukuran variabel kecemasan dilakukan dengan menggunakan buku harian ibu hamil, pedoman wawancara, dan pedoman observasi. Buku harian ibu hamil merupakan instrumen penggali data kuantitatif dan kualitatif. Buku harian ibu hamil merupakan buku yang wajib diisi partisipan selama 21 hari (7 hari baseline dan 14 hari intervensi). Buku harian ibu hamil memiliki skala rating tiap hari nya yang bertujuan untuk mengukur kecemasan. Skala disusun menggunakan blueprint kecemasan yang terdiri dari aspek fisik (enam indikator) dan aspek psikologis (lima indikator) (Fariana, 2007).

Partisipan diminta untuk memberikan skor pada tiap indikator dari 1 untuk perilaku tidak terjadi hingga skor 10 untuk perilaku sangat sering terjadi. Analisis skala dilakukan dengan menjumlahkan total skor tiap aspek tiap harinya, lalu membandingkannya dengan kondisi yang berbeda. Selain skala, buku harian juga memiliki pengumpul data kualitatif berupa lembar harian tempat partisipan bercerita mengenai perasaan, pikiran, dan apa yang dilakukan partisipan setiap hari. Selain itu, terdapat lembar untuk partisipan bercerita mengenai pengalaman praktik mandiri yang dilakukannya.

Wawancara dilakukan dua kali, yaitu sebelum dan sesudah intervensi diberikan. Pedoman wawancara disusun berlandaskan aspek-aspek kecemasan ibu hamil dari Fariana (2007) . Pedoman wawanacra akhir bertujuan untuk menggali ada atau tidaknya perubahan yang dialami partisipan bila dibandingkan dengan sebelum intervensi diberikan. Pedoman observasi disusun dengan tujuan untuk mengamati segala tingkah laku yang dilakukan partisipan selama pelatihan mindfulness berjalan. Pencatatan dilakukan secara naratif sistematis.

\section{Analisis Efektivitas Intervensi}

Analisis dilakukan dengan dua tahapan, yaitu analisis data keseluruhan dan analisis tiap partisipan. Analisis data keseluruhan bertujuan untuk menggambarkan perbedaan rata-rata skor kecemasan kehamilan antara kondisi baseline dan kondisi intervensi pada ketiga partisipan. Analisis tiap partisipan dilakukan dengan teknik statistik deskriptif melalui analisa visual grafik secara kuantitatif dan kualitatif. Analisis kuantitatif dilakukan dengan menerjemahkan skor skala rating buku harian menjadi grafik, lalu dilakukan perhitungan analisis dalam kondisi dan perhitungan analisis antar kondisi. Sebagai tambahan, analisis kualitatif dilakukan berdasar pada cerita naratif buku harian ibu hamil, hasil observasi selama pelatihan berlangsung, dan wawancara.

\section{ANALISIS EFEKTIVITAS INTERVENSI}

Partisipan 1 memiliki nilai rata-rata skor kecemasan kehamilan 30 untuk fase baseline dan 18,84 untuk fase intervensi. Partisipan 2 memiliki skor fase baseline 19,71 dan skor fase intervensi 23,86. Partisipan 3 memiliki skor fase baseline 40,86 dan skor fase intervensi 25,93. Berdasarkan rata-rata hasil pengukuran fase baseline dan fase intervensi kecemasan kehamilan, penurunan kecemasan kehamilan hanya terjadi pada partisipan 1 dan partisipan 3, sedangkan pada partisipan 2 tidak mengalami penurunan. Berikut adalah grafik rata-rata skor kecemasan kehamilan pada ketiga partisipan: 


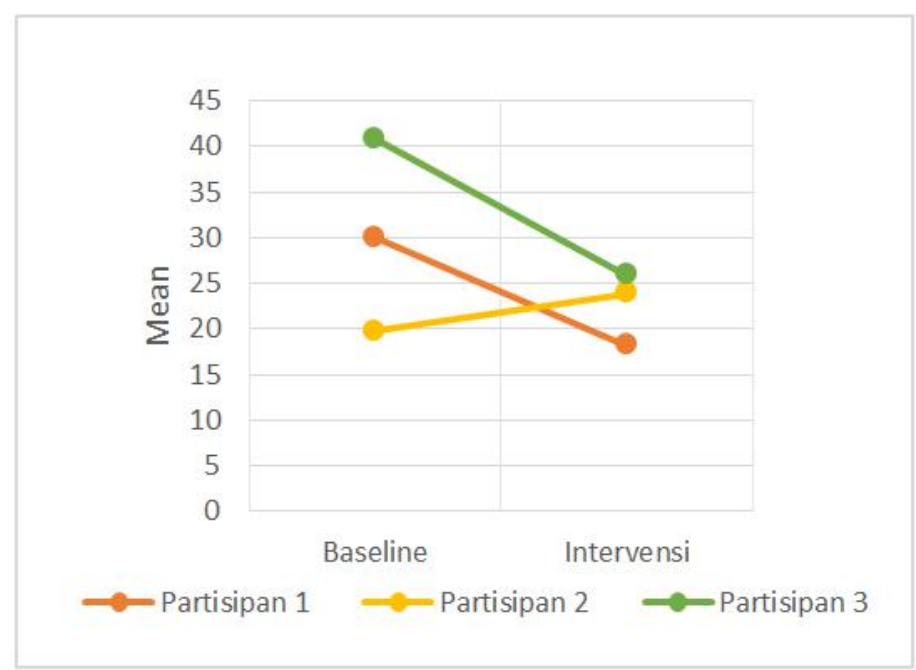

Grafik 1. Rata-Rata Hasil Pengukuran Fase Baseline dan Fase Intervensi Kecemasan Kehamilan

\section{Analisis Data Partisipan 1}

Berdasarkan perbandingan fase baseline dan fase intervensi kecemasan kehamilan Partisipan 1, terdapat penurunan rata-rata skor kecemasan kehamilan dari 30 pada kondisi baseline menjadi 18,84 pada kondisi intervensi.

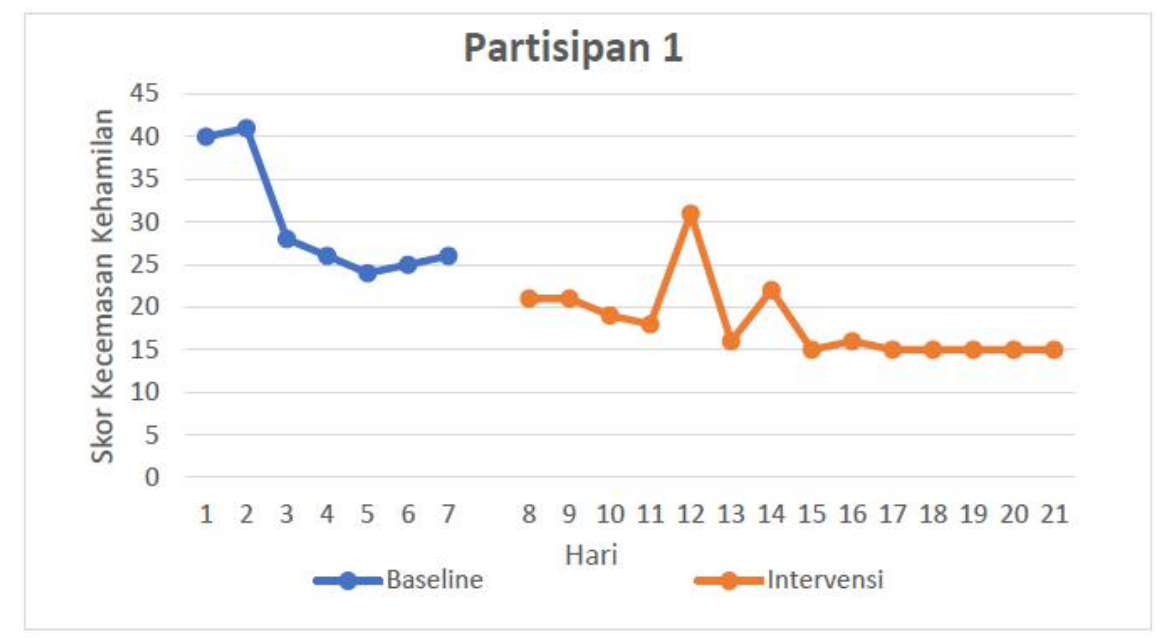

Grafik 2. Perbandingan Fase Baseline dan Fase Intervensi Kecemasan Kehamilan Partisipan 1

Berdasarkan perhitungan analisis dalam kondisi terhadap Grafik 2, hasil estimasi kecenderungan arah pada fase baseline dan fase intervensi keduanya mengalami penurunan. Presentase kecenderungan stabilitas didapatkan dari menghitung presentase banyaknya data yang berada dalam rentang batas atas dan batas bawah pada tiap fase. Pada fase baseline didapatkan bahwa 5 dari 7 data berada diantara rentang batas. Pada fase intervensi didapatkan bahwa 13 dari 14 data berada diantara rentang batas. Hasil tersebut menunjukkan presentase kecenderungan stabilitas pada fase baseline sebesar 71,43 persen dan bersifat variabel atau tidak stabil, sedangkan pada fase intervensi sebesar 92,86 persen dan bersifat stabil. Data yang dikatakan stabil adalah data yang memiliki presentase sebesar 80-90 persen (Sunanto, Takeuchi, \& Nakata, 2005). Perubahan level dihitung dengan

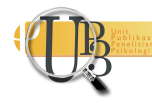


mengurangi skor pertama dan skor terakhir pada tiap kondisi. Berdasarkan perhitungan perubahan level, fase baseline memiliki level perubahan sebesar 14 dengan hasil positif (kecenderungan perubahan membaik) dan fase intervensi memiliki level perubahan sebesar 6 dengan hasil positif (kecenderungan perubahan membaik).

Berdasarkan perhitungan analisis antar kondisi dari Grafik 2, dapat diketahui bahwa kecenderungan arah grafik fase baseline dan fase intervensi keduanya menurun dengan perubahan positif. Penentuan level perubahan dilakukan dengan mengurangi nilai skor data pertama fase intervensi dengan data terakhir fase baseline. Level perubahan pada Grafik 2. terjadi sebesar 5 dengan grafik menurun sehingga menunjukkan perubahan yang positif. Penentuan overlap dilakukan dengan menghitung banyaknya data fase intervensi yang berada pada rentang kondisi fase baseline dibagi dengan banyaknya data fase intervensi dan dikalikan 100 persen, yaitu 1 dibagi 14 dikalikan 100 persen yaitu $7,14 \%$.

\section{Analisis Data Partisipan 2}

Berdasarkan perbandingan fase baseline dan fase intervensi kecemasan kehamilan partisipan 2, terdapat kenaikan skor kecemasan kehamilan dari 19,71 pada kondisi baseline menjadi 23,86 pada kondisi intervensi.

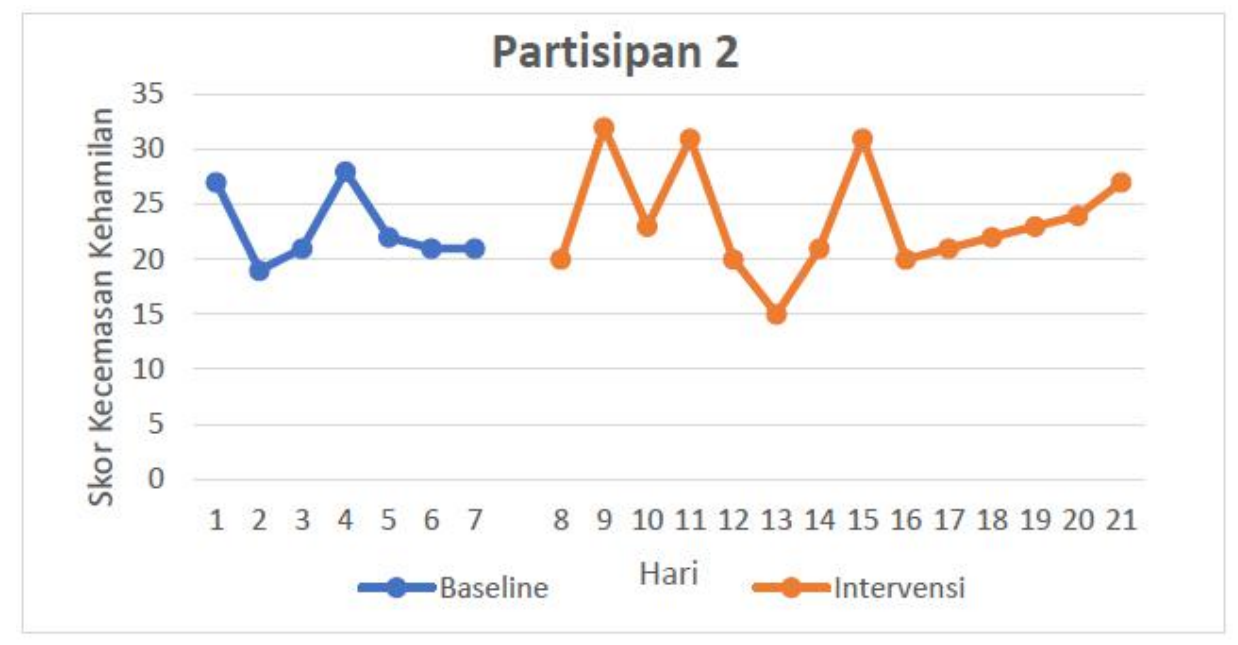

Grafik 3. Grafik Perbandingan Fase Baseline dan Fase Intervensi Kecemasan Kehamilan Partisipan 2

Berdasarkan perhitungan analisis dalam kondisi terhadap Grafik 3, hasil estimasi kecenderungan arah pada fase baseline mengalami peningkatan, sedangkan fase intervensi mengalami kecenderungan arah grafik yang menurun pada hari ke-8 hingga hari ke-13 dan grafik meningkat pada hari ke-14 hingga hari ke-21. Presentase kecenderungan stabilitas pada fase baseline sebesar 71,43 persen dan bersifat variabel atau tidak stabil dan pada fase intervensi sebesar 78,57 persen dan bersifat variabel atau tidak stabil. Perubahan level pada fase baseline terjadi sebesar 6 dengan hasil positif (kecenderungan perubahan membaik) dan fase intervensi memiliki level perubahan sebesar 7 dengan hasil negatif (kecenderungan perubahan memburuk).

Berdasarkan perhitungan analisis antar kondisi dari Grafik 3, dapat diketahui bahwa kecenderungan arah grafik fase baseline dan fase intervensi meningkat dengan perubahan negatif. Level perubahan pada Grafik 3. hanya terjadi sebesar 1 dengan grafik menurun sehingga sedikit menunjukkan

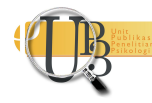


perubahan yang positif. Persentase overlap data fase intervensi yang berada pada rentang kondisi fase baseline yaitu sebesar 64,28 persen.

\section{Analisis Data Partisipan 3}

Berdasarkan perbandingan fase baseline dan fase intervensi kecemasan kehamilan partisipan 3 menunjukkan bahwa terdapat penurunan skor kecemasan kehamilan Partisipan 3 dari 40,86 pada fase baseline menjadi 25,93 pada fase intervensi.

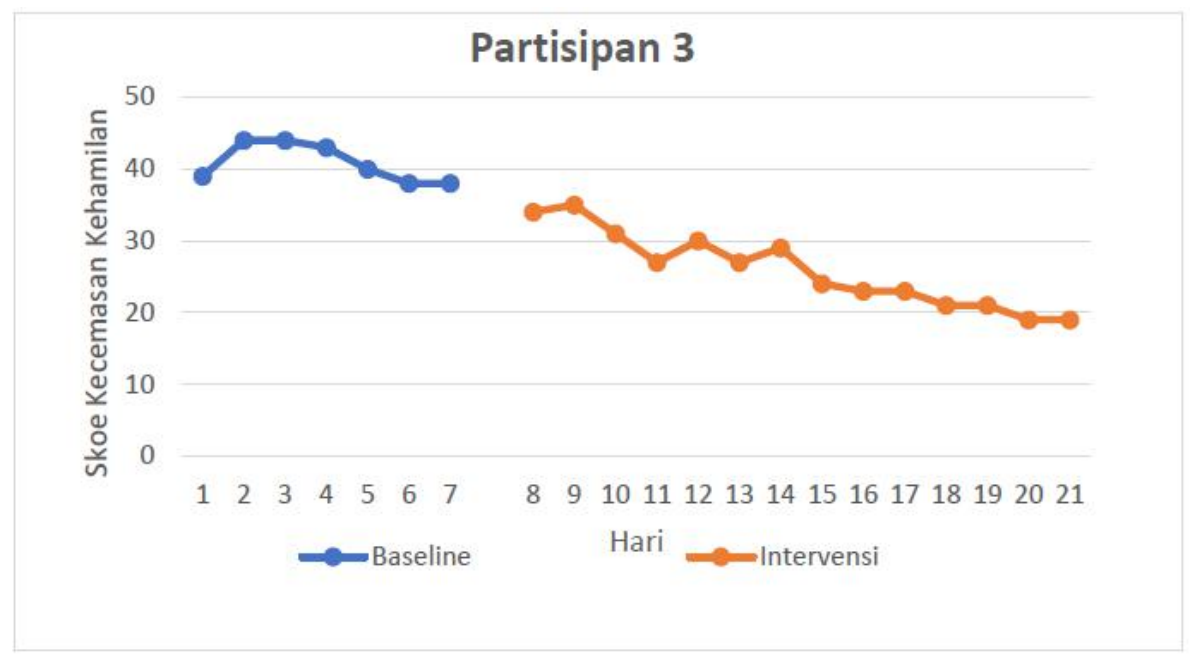

Grafik 4. Grafik Perbandingan Fase Baseline dan Fase Intervensi Kecemasan Kehamilan Partisipan 3

Berdasarkan perhitungan analisis dalam kondisi terhadap Grafik 4, hasil estimasi kecenderungan arah pada fase baseline dan fase intervensi keduanya mengalami penurunan. Presentase kecenderungan stabilitas pada fase baseline sebesar 100 persen dan bersifat stabil, sedangkan pada fase intervensi sebesar 71,42 persen dan bersifat variabel atau tidak stabil. Perubahan level fase baseline terjadi sebesar 1 dengan hasil positif (kecenderungan perubahan membaik) dan fase intervensi memiliki level perubahan sebesar 15 dengan hasil positif (kecenderungan perubahan membaik).

Berdasarkan perhitungan analisis antar kondisi dari Grafik 4, dapat diketahui bahwa kecenderungan arah grafik kondisi baseline dan kondisi intervensi keduanya menurun dengan perubahan positif. Level perubahan pada Grafik 4. terjadi sebesar 4 dengan grafik menurun sehingga menunjukkan perubahan yang positif. Persentase overlap data fase intervensi yang berada pada rentang kondisi fase baseline yaitu sebesar 7,14 persen.

\section{I S K U S I}

Hasil analisis secara keseluruhan menunjukkan bahwa intervensi berupa pelatihan mindfulness untuk menurunkan kecemasan tidak berdampak pada seluruh partisipan. Penurunan kecemasan sebagai pengaruh dari pelatihan mindfulness hanya terjadi pada partisipan 1 dan partisipan 3, sedangkan pada partisipan 2 tidak mengalami penurunan. Hal tersebut merupakan hasil dari perhitungan level perubahan grafik pada partisipan 1 dan partisipan 3 yang mengalami perubahan positif, sedangkan pada partisipan 2 perubahan yang terjadi adalah negatif. Selain itu, data partisipan 1 dan partisipan 3 memiliki nilai overlap yang kecil yaitu 7,14 persen, sedangkan nilai overlap partisipan 2 cukup tinggi

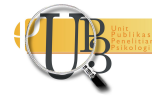


yaitu 64,28 persen. Semakin kecil nilai overlap maka intervensi memberikan pengaruh yang semakin baik (Sunanto, Takeuchi, \& Nakata, 2005) . Sehingga dapat dikatakan pada partisipan 2 intervensi berupa pelatihan mindfulness kurang dapat memberikan pengaruh yang positif.

Penurunan kecemasan kehamilan partisipan 1 dan partisipan 3 sesuai dengan pernyataan Roomer dan Orsillo (Brown, Creswell, \& Ryan, 2015), bahwa ketiga komponen utama pelatihan mindfulness dapat mereduksi faktor penyebab kecemasan khususnya dari sisi kognitif. Menurut Zinn, pada dasarnya, pelatihan mindfulness memiliki tiga komponen utama yaitu kesadaran terbuka, fokus saat ini, dan sikap tidak menghakimi pengalaman hidup yang sedang dilalui (Brown, Creswell, \& Ryan, 2015) . Kesadaran terbuka merubah pemikiran sempit penyebab kecemasan ibu hamil dengan mengambil konteks pengalaman yang sebenar-benarnya sehingga mengarah pada pikiran yang lebih netral dan positif. Fokus saat ini, membantu ibu hamil untuk menikmati dan berkonsentrasi dengan pegalaman kehamilan sehingga ketika dihadapkan dengan suatu masalah, ibu dapat fokus untuk mencari jalan keluar terbaik. Sikap tidak menghakimi, meningkatkan penerimaan ibu hamil pada pengalaman yang terjadi dengan tidak memberikan nilai baik atau buruk, dan juga tidak mengaitkan dengan aspek pribadi, melainkan menerima pemikiran dan perasaan pribadi apa adanya dan menjadikan sebagai pengalaman yang akan datang dan pergi (Brown, Creswell, \& Ryan, 2015).

Keberhasilan pelatihan mindfulness dalam menurunkan kecemasan partisipan 1 dan partisipan 3 mendukung penelitian terdahulu yang dilakukan oleh Maharani (2013) pada remaja hamil pranikah, bahwa pelatihan mindfulness mampu memaksimalkan sumber daya internal dan menurunkan tingkat stres. Taylor, Cavanagh, dan Strauss (2016) juga mengungkapkan bahwa pelatihan mindfulness memang sangat cocok untuk mendukung kesehatan dan mengarahkan ibu hamil pada kebahagiaan.

Berdasarkan hasil wawancara, sebelum pelatihan diberikan partisipan 1 memiliki kecemasan yang bersumber dari dirinya sendiri yaitu berkaitan dengan riwayat kesehatan yang memiliki gangguan Polycystic Ovarian Syndrome (PCOS) dan juga pengalaman sulit memiliki anak selama 6 tahun. Selain itu partisipan juga memiliki tuntutan pekerjaan yang besar sehingga merasa takut dan cemas kesibukkannya akan berdampak negatif bagi janin yang dikandungnya. Setelah mengikuti pelatihan, partisipan dapat menginternalisasi mindfulness yang mana dirinya membiasakan diri untuk peka, fokus, dan sadar terhadap kondisi fisik dan psikologis. Partisipan sadar penuh bahwa kehidupan janin bergantung pada kesehatan dirinya sebagai ibu.

Perubahan membaik juga terjadi pada partisipan 3. Sebelum pelatihan diberikan, partisipan memiliki kecemasan yang bersumber dari pemikiran salah pola asuh dalam merawat anak nantinya dan ketakutan tidak dapat memproduksi ASI. Ketakutan tersebut sempat sampai membuat partisipan menghakimi diri tidak normal karena membanding-bandingkan dirinya dengan ibu hamil lainnya. Kecemasan muncul karena pemikiran partisipan yang terlalu jauh kedepan dan tidak fokus dengan pengalaman saat ini. Setelah mengikuti pelatihan, partisipan mampu berpikir lebih sadar dan menghilangkan sikap menghakimi diri sendiri yang dimilikinya. Partisipan semakin menghayati proses kehamilan, merasakan kebahagiaan, dan tidak ingin membandingkan dirinya dengan orang lain.

Perbedaan tren terjadi pada partisipan 2, yaitu mengalami kenaikan dan penurunan yang fluktuatif. Hal tersebut menunjukkan data yang tidak stabil dikarenakan terdapat faktor tertentu yang memengaruhinya. Berdasarkan hasil wawancara, partisipan berprofesi sebagai dokter muda yang sedang menjalani proses co-asisten di salah satu rumah sakit umum daerah. Terdapat faktor pengalaman yang memengaruhi partisipan 2. Hal tersebut sesuai dengan pernyataan Spielberg dan Saranson bahwa pengalaman yang dialami ibu hamil selama proses kehamilan dapat memengaruhi timbulnya kecemasan (Hidayati, 2014). Pengalaman memengaruhi timbulnya distorsi kognitif partisipan 2 dengan memunculkan penghakiman dan pemikiran yang sempit terkait kondisi kehamilannya. Pengalaman tersebut terjadi dalam wujud partisipan merefleksikan apa yang dilihat INSAN Jurnal Psikologi dan Kesehatan Mental 2021, Vol. 6(1), 10-21

doi: 10.20473/jpkm.v6i12021.10-21

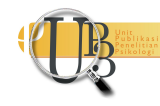


ketika partisipan sedang menjalani praktik koas. Pada awal penelitian, partisipan bekerja pada stase rehabiltitasi medis, sehingga partisipan memiliki pengalaman melihat anak-anak berkebutuhan khusus dan beratnya perjuangan orangtua yang mendampingi anak tersebut. Selain itu, selama akhir penelitian partisipan bekerja di stase obsgyn sehingga partisipan memiliki pengalaman melihat secara langsung berbagai keadaan ibu hamil dan juga turut membantu persalinan ibu hamil. Maka dari itu dapat disimpulkan partisipan dipengaruhi oleh pengalaman yang benar-benar terkait dengan kondisi kehamilannya.

Sebagai tambahan, partisipan 2 memiliki beban kerja lebih tinggi dibanding partisipan lainnya. Pekerjaan sebagai dokter muda menjadi job stress bagi partisipan 2 yang sedang menginjak usia kehamilan trimester III. Job stress merupakan suatu tekanan psikologis yang dirasakan dalam hubungannya dengan ketidakmampuan untuk merespon atau mengendalikan suatu situasi di tempat kerja secara bijaksana (Khan, dkk., 2017). Partisipan sebagai ibu yang sedang hamil trimester III memiliki tekanan psikologis ketika harus mengikuti banyaknya kegiatan, beratnya pekerjaan, dan padatnya jadwal di rumah sakit. Hal tersebut didukung oleh penelitian yang membuktikan bahwa semakin tinggi aktivitas fisik yang dilakukan, maka semakin tinggi pula kecemasan pada individu yang berprofesi dibidang kesehatan (Lindwall, Gerber, Jonsdottir, \& Borjesson, 2014).

Berdasarkan uraian tersebut, dapat disimpulkan bahwa pada partisipan 2 pelatihan mindfulness tidak memberikan pengaruh dalam mereduksi kecemasan kehamilan dikarenakan partisipan lebih dipengaruhi oleh adanya faktor pengalaman kuat yang didapatkan dari lingkungan kerja. Selain itu, beban kerja partisipan 2 juga menjadi dasar kecemasan kehamilan tidak menurun. Kecemasan yang dicirikan dengan pemikiran sempit, reaktif, khawatir, gelisah dan sikap menghakimi terkait kehamilan masih tetap ada. Partisipan 2 belum dapat menginternalisasi secara penuh komponen pelatihan mindfulness yang meliputi kesadaran terbuka, fokus, dan sikap tidak menghakimi.

\section{S I M P U L A N}

Berdasarkan hasil analisis efektivitas intervensi yang telah dipaparkan, maka dapat disimpulkan bahwa intervensi berupa pelatihan mindfulness dapat memberikan pengaruh untuk menurunkan kecemasan kehamilan, hanya saja tidak pada seluruh partisipan. Penurunan kecemasan kehamilan hanya terjadi pada dua dari tiga partisipan yang mengikuti pelatihan. Hal tersebut dikarenakan adanya faktor pemicu timbulnya kecemasan yang lebih intens pada salah satu partisipan.

Pelatihan mindfulness dapat dijadikan alternatif intervensi psikologis untuk menurunkan kecemasan ibu hamil. Pelatihan mindfulness membawa efek positif yang bermakna pada aspek fisik dan aspek psikologis di kedua partisipan.

Sebagai saran bagi praktisi selanjutnya, dapat lebih memperluas rentang waktu latihan mindfulness, memperhatikan lebih jauh terkait latihan mandiri agar lebih maksimal, dan menaruh perhatian pada sumber masalah atau faktor pemicu timbulnya kecemasan pada tiap partisipan.

\section{U C A P A N T ER IMA KA S I H}

Penulis berterima kasih kepada Annisa Poedji Pratiwi, M.Psi., psikolog yang telah bersedia menjadi fasilitator pelatihan Mindfulness sehingga penelitian ini dapat diwujudkan dan terselesaikan dengan baik. Penulis juga menyampaikan terimakasih pada seluruh Partisipan ibu hamil yang telah bersedia secara kooperatif meluangkan waktu, sehingga proses keberjalanan pelatihan dapat berjalan dengan tepat waktu dan efektif. 


\section{DEKLARASI POTENSI TERJADINYA KONFLIK KEPENTINGAN}

Nurul Hapsari, Suci Murti Karini, dan Arif Tri Setyanto tidak bekerja, menjadi konsultan, memiliki saham, atau menerima dana dari perusahaan atau organisasi mana pun yang akan mengambil untung dari naskah ini, dan telah mengungkapkan bahwa ia tidak memiliki afiliasi selain yang telah disebut di atas.

\section{PUSTAKA ACUAN}

Biaggi, A., Conroy, S., Pawlby, S., \& Pariante, C. (2016). Identifying the women at risk of antenatal anxiety and depression: a systematic review. Journal of Affect Disorder, 191, 62-67.

Bora, B., Rahman, R., \& Hasina, M. J. (2013). A comparative study of serum prolactin and cortisol during labour and after delivery. International Journal of Psychology, 1(01).

Brown, K. D., Creswell, J. D., \& Ryan, R. M. (2015). Handbook of Mindfulness: Theory, Research, and Practice. London: The Guilford Press.

Fariana, Y. (2007). Pengaruh terapi relaksasi otot terhadap kecemasan ibu hamil pertama trimester ketiga. Tesis Sarjana Strata II. Program Studi Magister Profesi Psikologi Universitas Surabaya.

Goodman, J. H., Guarino, A., Chenausky, K., Klein, L., Prager, J., Petersen, R., dkk. (2013, December). CALM pregnancy: results of a pilot study of mindfulness-based cognitive therapy for perinatal anxiety. Article Archives of Womens Mental Health, 17(5), 373-387.

Handayani, R. (2015). Faktor-faktor yang berhubungan dengan tingkat kecemasan menjelang persalinan pada ibu primigravida trimester III di wilayah kerja Puskesmas Lubuk Buaya Padang tahun 2012. Ners Jurnal Keperawatan, 11(1), 62-71.

Hidayati, D. S. (2014). Latar belakang psikologis kecemasan ibu hamil usia 35 tahun keatas. Jurnal Ilmiah Psikologi Terapan, 2(02), 325-334.

Hurlock, E. (1990). Psikologi Perkembangan: Suatu Pendekatan Sepanjang Rentang Kehidupan (Edisi Kelima). Jakarta: Airlangga.

Huzink, A. C., Menting, B., Moor, M. H., Verhage, M. L., Kunseler, F. C., Schuengel, C., dkk. (2017). Arch Womens Mental Health, 20, 663-672.

Khan, A., Amanat, A., Aqeel, M., Sulehri, N. A., Sana, E., Amin, H., dkk. (2017). The meditating role of job stress between social support and development of stress, anxiety and depression in educators and health professionals. Foundation University Journal of Psychology, 1(01), 38-55.

Lindwall, M., Gerber, M., Jonsdottir, I. H., \& Borjesson, M. (2014). The relationships of change in physical activity with change in depression, anxiety, and burnout: a longitudinal study of Swedish healthcare workers. Journal of Health Psychology American Psychological Association, 33(11), 1309-1318.

Litsmanasari, A., \& Warsiti. (2013). Perbedaan tingkat kecemasan menghadapi persalinan pada ibu primigravida dan multigravida trimester III di puskesmas sanden bantul. Skripsi. Program Studi Ilmu Keperawatan Stikes Aisyiyah Yogyakarta.

Maharani, E. A. (2013). Pengaruh pelatihan meditasi sadar diri terhadap penurunan tingkat distress remaja yang mengalami kehamilan pranikah. Tesis. Universitas Gajah Mada, Yogyakarta.

INSAN Jurnal Psikologi dan Kesehatan Mental

2021, Vol. 6(1), 10-21

doi: 10.20473/jpkm.v6i12021.10-21

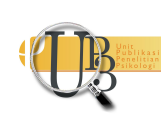


McManus, F., Surawy, C., Muse, K., Montez, M. V., \& Williams, J. M. (2012). A randomized clinical trial of mindfulness-based cognitive therapy versus unrestricted services for health anxiety (hypochondriasis). Journal of Consulting and Clinical Psychology, 80(5), 817-828.

Pan, Y., Cai, W., Cheng, Q., Dong, W., An, T., \& Yan, J. (2015). Association between anxiety and hypertension: a systematic review and meta-analysis of epidemiological studies. Journal Neuropsychiatric Disease and Treatment, 11, 1121-1130.

Schermerhorn, D. (2015). The role of anxiety in the development of suicidal thoughts in pregnant women with mood disorders. Tesis. Buston University.

Schetter, C. D., \& Tanner, L. (2012). Anxiety, Deppression, and Stress in Pregnancy: Implications for mothers, children, research, and practice. Current Opinion in Psychiatry, 25, 141-148.

Sunanto, J., Takeuchi, K., \& Nakata, H. (2005). Pengantar Penelitian dengan Subjek Tunggal. Jepang: University of Tsukuba.

Taylor, B. L., Cavanagh, K., \& Strauss, C. (2016). The effectiveness of mindfulness-based interventions in the perinatal period: a systematic review and meta-analysis. PLoS One, 11(5), e0155720.

Wulandary, P. (2014). Tingkat kecemasan ibu hamil primigravida trimester III dalam menghadapi persalinan di puskesmas sibela mojosongo tahun 2014. Skripsi. Program Studi Diploma III Kebidanan Sekolah Tinggi Ilmu Kesehatan Kusuma Husada Surakarta.

Zarbock, G., Lynch, S., Ammann, A., \& Ringer, S. (2015). Mindfulness for Therapies: Understanding Mindfulness for Professional Effectiveneess and Personal Well-being. UK: Wiley Blackwell. 